\title{
Properties of Whey Protein Isolates Extruded under Acidic and Alkaline Conditions ${ }^{1}$
}

\author{
C. I. Onwulata, ${ }^{\star 2}$ S. Isobe, $†$ P. M. Tomasula, ${ }^{*}$ and P. H. Cooke ${ }^{\star}$ \\ *USDA-ARS, Eastern Regional Research Center, 600 East Mermaid Lane, Wyndmoor, PA 19038 \\ †Food Engineering Division, National Food Research Institute, Tsukuba, Ibaraki, Japan
}

\begin{abstract}
Whey proteins have wide acceptance and use in many products due to their beneficial nutritional properties. To further increase the amount of whey protein isolates (WPI) that may be added to products such as extruded snacks and meats, texturization of WPI is necessary. Texturization changes the folding of globular proteins to improve interaction with other ingredients and create new functional ingredients. In this study, WPI pastes (60\% solids) were extruded in a twin-screw extruder at $100^{\circ} \mathrm{C}$ with $4 \mathrm{pH}$-adjusted water streams: acidic $(\mathrm{pH} 2.0$ $\pm 0.2)$ and alkaline $(\mathrm{pH} 12.4 \pm 0.4)$ streams from $2 N$ $\mathrm{HCl}$ and $2 \mathrm{~N} \mathrm{NaOH}$, respectively, and acidic $(\mathrm{pH} 2.5$ $\pm 0.2)$ and alkaline $(\mathrm{pH} 11.5 \pm 0.4)$ electrolyzed water streams; these were compared with WPI extruded with deionized water. The effects of water acidity on WPI solubility at $\mathrm{pH} \mathrm{7,} \mathrm{color,} \mathrm{microstructure,} \mathrm{Rapid} \mathrm{Visco}$ Analyzer pasting properties, and physical structure were determined. Alkaline conditions increased insolubility caused yellowing and increased pasting properties significantly. Acidic conditions increased solubility and decreased WPI pasting properties. Subtle structural changes occurred under acidic conditions, but were more pronounced under alkaline conditions. Overall, alkaline conditions increased denaturation in the extruded WPI resulting in stringy texturized WPI products, which could be used in meat applications.
\end{abstract}

Key words: $\mathrm{pH}$, extrusion, whey protein isolates, electrolyzed water

\section{INTRODUCTION}

Extruders provide mechanical and thermal energy for mixing, cooking, melting, and forming biomaterials. A demonstrated benefit of extrusion processing is the abil-

Received June 28, 2005.

Accepted September 14, 2005.

${ }^{1}$ Mention of trade names or commercial products in this publication is solely for the purpose of providing specific information and does not imply recommendation or endorsement by U.S. Department of Agriculture.

${ }^{2}$ Corresponding author: conwulata@errc.ars.usda.gov ity to change the molecular structure of food ingredients (Batterman-Azcona and Hamaker, 1998). Because extrusion processing offers versatility in forming materials for various functional uses, there has been a steady increase in food products created by this technology. These products include breakfast cereals, snacks, meal replacement bars, and confectionery candies (Breitenbach, 2002).

The use of extrusion to impart fibrous texture to plant proteins for use as meat extenders has been practiced for many years (Atkinson, 1970). Rhee et al. (1981) reviewed the processes for texturization of soy proteins. High moisture ( $\geq 60$ weight $\%$ ) and temperatures above $150^{\circ} \mathrm{C}$ are needed for texturizing and forming fibrous structures by extrusion from soy isolates (Kitabatake et al., 1985). Extrusion shear-induced fibrous networks are formed through formation of disulfide bonds, and crosslinking of protein chains through amide bonds between free-carboxyl and amino side groups (Harper, 1981). Adjustment of $\mathrm{pH}$ through acid or alkali treatment influences conformation, molecular interactions of proteins, and development of structure in soy proteins (Dahl and Villota, 1991). Whey proteins can be modified using chemicals, heat, or shear in extrusion processes. Chemical treatment alone alters the reactive groups of the amino acids, resulting in changes in the noncovalent forces that influence conformation, such as van der Waals forces, electrostatic interactions, hydrophobic interactions, and hydrogen bonding (Kester and Richardson, 1984).

For whey proteins, texturization is more difficult to accomplish. Whey proteins are degraded by prolonged heat treatment above $140^{\circ} \mathrm{C}$ (Walstra et al., 1999). Thermal denaturation of the 2 major protein fractions in whey protein isolates, $\beta$-lactoglobulin (50\%) and $\alpha$-lactalbumin (22\%), takes place between 50 and $75^{\circ} \mathrm{C}$ and is accompanied by unfolding and unmasking of the $\mathrm{SH}$ groups (Linden and Lorient, 1999). When the whey proteins are denatured, they become insoluble, and aggregate (Walstra et al., 1999). The extent of denaturation is determined by proportion of protein insoluble at $\mathrm{pH} 7$ and depends on heating temperature, time, and the $\mathrm{pH}$ of whey at heating (Ennis and Mulvihill, 2000). Moreover, adjusting the acidity $\left(\mathrm{H}^{+}\right)$or alkalinity $\left(\mathrm{OH}^{-}\right)$of whey 
proteins while heating increases loss of solubility, and denaturation (Harwalker, 1979). However, during texturization in the extruder, insoluble cross-linked protein aggregates are aligned by flow and complex shearing action of the extruder screws (Queguiner et al., 1992).

Heating and shear alter the conformational structure of the whey protein through partial denaturation of the protein, thereby exposing groups that are normally concealed in the native protein (Kim and Maga, 1987). By varying extrusion temperatures and denaturing whey proteins at temperatures below $100^{\circ} \mathrm{C}$, various textured protein products were created that retained their physical functionality such as foaming and digestibility (Hale et al., 2002; Onwulata et al., 2003; Onwulata and Tomasula, 2004). Differences in the interaction of denatured whey depending on $\mathrm{pH}$ have been reported in milk (Anema et al., 2004). Anema et al. (2004) showed, for instance, that at $\mathrm{pH} 6.5$, about $70 \%$ of the denatured $\beta$ LG and $\alpha$-LA were associated with casein, whereas at $\mathrm{pH}$ 6.7, only about $30 \%$ were associated with casein.

Electrolyzed water has been used as an adjunct for enhanced food quality and safety in Japan, and its use has been reported to improve kneading quality of wheat flour and dough alone without using other food additives (Kato et al., 2001). Improvement in the textural properties of Japanese rice cooked with electrolyzed water $\mathrm{pH}$ 9 to 10) was also reported by the same authors. Kobayashi et al. (1996) reported increased volume and texture, as measured by the adhesiveness and hardness ratio, signifying the effect of $\mathrm{pH}$ on protein structure and function. Therefore, the use of electrolyzed water in affecting structural changes in proteins was worth investigating. Because small shifts in $\mathrm{pH}$ affect milk protein structure, this study was conducted to determine the effect of $\mathrm{pH}$ with extrusion shear on texturization of whey protein isolates and the resulting effects on physical properties of the extrudates.

\section{MATERIALS AND METHODS}

\section{Materials}

Whey protein isolate (WPI) Provon 190 purchased from Glanbia Ingredients (Glanbia Foods Inc., Richfield, ID) was used for this work. Electrolyzed water for the acid or alkaline extrudates was generated with an Amano 800 electrolyzer (Amano USA Inc., Roseland, NJ) at $\mathrm{pH}$ of $2.0 \pm 0.2$ and $11.5 \pm 0.2$, respectively, for comparison studies. Nonelectrolyzed $\mathrm{pH}$-adjusted water was also prepared. For acid, water was adjusted to $\mathrm{pH}$ of $1.4 \pm$ 0.2 with $2 \mathrm{~N} \mathrm{HCl}$, and alkali to $\mathrm{pH} 12.5 \pm 0.2$ with $2 \mathrm{~N}$ $\mathrm{NaOH}$. Electrolyzed water was generated by electrolysis of sodium chloride solution producing low $\mathrm{pH}$ water at the anode $(\mathrm{HCl})$ and hypochlorous $\left(\mathrm{OCl}^{-}\right)$at the cathode. Acidic electrolyzed water (AcEW) was generated using a flow type electrolysis apparatus (ROX-20TA, Hoshizaki Electric Co. Ltd., Toyoake, Aichi, Japan). The current passing through the electrolysis apparatus was set at $16 \mathrm{~A}$, and the voltage between the electrodes was set at $18 \mathrm{~V}$. Acidic electrolyzed water (40 ppm free available chlorine) was prepared within the anode compartment of an electrolytic cell and alkaline electrolyzed water (AlEW) was prepared within the cathode compartment. The properties of each solution were determined, including $\mathrm{pH}$ and free available chlorine concentration. The $\mathrm{pH}$ of the tested solution was measured with a $\mathrm{pH}$ meter (HM-11P, Toa Electronics Ltd., Tokyo, Japan). Within $1 \mathrm{~h}$, the initial concentration of the free available chlorine was determined with EPA-approved chlorine test kits (Hach Co., Loveland, CO). Estimated $\mathrm{pH}$ values were $2.6 \pm 0.1,11.4 \pm 0.1$, and $6.8 \pm 0.1$ for AcEW, AlEW, and deionized water (DW), respectively. Free available chlorine concentration of AcEW and chlorinated water was $40.3 \pm 1.5 \mathrm{ppm}$.

\section{Extrusion Processing}

The screw profile of the Krupf Werner Pfleiderer ZSK30 twin-screw extruder used for this study was reported earlier (Onwulata et al., 2001). The screw speed of the extruder was maintained at $200 \mathrm{rpm}$. The screw elements were selected to provide low shear at $200 \mathrm{rpm}$. The barrel temperature profile for extrusion was 35,35 , $35,50,100,100,100,100$, and $100^{\circ} \mathrm{C}$, from the feed section to the die. Water input to the extruder was at the rate of $23 \mathrm{~g} / \mathrm{min}$. The $\mathrm{pH}$-adjusted water was injected with an electromagnetic dosing pump (Milton Roy, Acton, MA) to bring the moisture content of the feed to approximately $20 \mathrm{~g}$ of $\mathrm{H}_{2} \mathrm{O} / 100 \mathrm{~g}$ of mixture (wet basis). Feed rate of WPI was $35 \mathrm{~g} / \mathrm{min}$ and WPI extrudates assayed were coded as follows: NEXT $=$ nonextruded WPI (control); HACI $=$ WPI extruded at $\mathrm{pH} 2.0 \pm 0.2(\mathrm{pH}$ was adjusted with $2 \mathrm{~N} \mathrm{HCl}$ ); NEUT (extrudate control) = WPI extruded at pH $6.8 \pm 0.2$ with DW; EACI $=$ WPI extruded at $\mathrm{pH} 2.5 \pm 0.4$ with AcEW; EALK = WPI extruded at $\mathrm{pH} 11.5 \pm 0.2$ with AlEW; and NALK = WPI extruded at $\mathrm{pH} 11.5 \pm 0.4$ with $2 \mathrm{~N} \mathrm{NaOH}$. Extruded WPI samples were collected, freeze-dried in a laboratory freeze dryer for $5 \mathrm{~min}$, and stored at $4.4^{\circ} \mathrm{C}$ until analyzed. Moisture content was measured using a vacuum oven (method \#925.09; AOAC, 1998).

\section{Buffering}

To understand the buffering effect of the WPI, nonextruded pastes of WPI and $\mathrm{pH}$-adjusted water streams were made by adding a specified acid or alkali to deionized water, and the pastes were made using a Hobart commercial mixer (The Hobart Mfg. Co., Troy, OH). Five 
different $\mathrm{pH}$ water streams were prepared as follows: pH 2.6 adjusted with $1 N$ HC1; pH 1.4 adjusted with 2 $N$ HCl; pH 6.8, deionized water; $\mathrm{pH} 11.6$ adjusted with $1 \mathrm{~N} \mathrm{NaOH}$; and $\mathrm{pH} 13$ adjusted with $2 \mathrm{~N} \mathrm{NaOH}$. Whey protein isolate pastes were made at the ratio of $60 \mathrm{~g}$ of $\mathrm{WPI} / 40 \mathrm{~mL}$ of the appropriate $\mathrm{pH}$-adjusted water stream, and $\mathrm{pH}$ was measured every $15 \mathrm{~s}$ for $2 \mathrm{~min}$. The maximum residence time of $\mathrm{pH}$-adjusted pastes in the extruder was recorded.

\section{Solubility}

Solubility of extruded WPI was determined with a 1.0g sample of extrudate stirred with $90 \mathrm{~mL}$ of deionized water at $125 \mathrm{rpm}$ and $\mathrm{pH} 7.0$ for $2 \mathrm{~h}$. Samples were then centrifuged at $5,000 \times g$ for $20 \mathrm{~min}$. The supernatant was freeze-dried overnight. The nitrogen/protein conversion factor was 6.38 and percentage protein solubility was calculated as described by Kilara (1984). Insolubility or denaturation was calculated as (100 - solubility).

\section{Color}

Tristimulus color measurements of WPI extrudates were measured instrumentally with a Hunter Laboratory (ColorQuest XE model) infrared spectrophotometer (Hunter Associates Laboratory, Inc., Reston, VA). Extrudates were scanned through a small-angle port $\left(2^{\circ}\right)$. Hunter $L^{*}, a^{*}, b^{*}$ values were used to calculate total color difference $(\Delta \mathrm{E})$, defined as the square root of $\left(\mathrm{L}^{2}\right.$ $+a^{2}+b^{2}$ ). Standard reference tile values were $L=93.5$; $\mathrm{a}=-0.89$; and $\mathrm{b}=1.01$, where $\mathrm{L}=$ lightness, $\mathrm{a}=$ redness, and $\mathrm{b}=$ yellowness.

\section{Rapid Visco Analyzer Pasting Viscosity}

Post-extrusion, pastes of texturized extrudates were made as described, to determine their viscosity. Analysis of the pasting behavior was conducted with a Rapid Visco Analyzer (RVA; model RVA-3D, Foss North America, Eden Prairie, MN) equipped with Thermocline for Windows software. Pasting properties, a measure of WPI paste viscosity, were determined by RVA Application Method No. 48, using a 28-g specimen, $13.5 \%$ wet basis (Parkes et al., 1998).

\section{Stereo Fluorescence and Confocal Microscopy}

Short $(1 \mathrm{~cm})$ segments of extruded ribbons were cut perpendicular to the axis of extrusion with a stainless steel razor blade by hand and sectioned surfaces were illuminated with either white light from a fiber-optic illuminator (model 190, Dolan-Jenner Industries, Inc., Woburn, MA) or violet light ( 425 to $440 \mathrm{~nm}$ ) from a high- pressure Hg lamp. Images were obtained with a stereo fluorescence microscope, equipped with a color CCD and digital imaging hardware and software (model MZ FLIII, Leica Microsystems, Inc., Bannockburn, IL). For confocal microscopy, the cut faces of ribbon segments were applied to the glass bottom of microwell dishes (MatTek Corp., Ashland, MA) and illuminated with blue light (488 $\mathrm{nm}$ ) from an argon laser. Maximum projection images of green autofluorescence (510 to $550 \mathrm{~nm}$ ) within approximately $30 \mu \mathrm{m}$-thick stacks of optical sections were collected using a $10 \times$ lens mounted in an optical microscope integrated with a spectrophotometric confocal microscope system (model IRBE, Leica Microsystems, Inc., Exton, PA). The distribution of intensity in digital images was analyzed using Fovea Pro3.0 plug-ins (Reindeer Graphics, Asheville, NC) with Photoshop v7.0 (Adobe Systems Inc., San Jose, CA).

\section{Transmission Electron Microscopy}

Small segments of extruded ribbons in glutaraldehyde fixative solution were trimmed into small blocks $(\sim 1 \times 2$ $\mathrm{mm}$ ) and washed in $0.1 \mathrm{M}$ imidazole buffer. Then, the blocks were immersed in $2 \%$ osmium tetroxide solution buffered with imidazole buffer for $2 \mathrm{~h}$, washed in distilled water, and gradually dehydrated in a series of ethanol solutions. After several changes of absolute ethanol, blocks were immersed in propylene oxide and transferred to a 1:1 mixture of propylene oxide and epoxy resin mixture and slowly agitated to promote infiltration of the plastic into the sample blocks. Following infiltration, the blocks were transferred to epoxy resin mixture and cured for $2 \mathrm{~d}$ at $55^{\circ} \mathrm{C}$. Thin sections of the cured blocks were stained with solutions of uranyl acetate and lead citrate, and then examined in the bright-field imaging mode using a electron microscope (model CM12, FEI Co., Inc., Hillsboro, OR). Images were recorded on photographic film at an instrumental magnification of $45,000 \times$.

\section{RESULTS AND DISCUSSION}

The buffering capacities of WPI pastes under different $\mathrm{pH}$ conditions are shown in Figure 1. Using the same amount of WPI $(60 \mathrm{~g})$ and $\mathrm{pH}$-adjusted water $(40 \mathrm{~mL})$, a paste with the same consistency as the paste that leaves the extruder was created and the buffering time depended on the initial $\mathrm{pH}$. Comparatively, $1 M \mathrm{HCl}$ of lower molarity weaker acids or bases took a shorter time, 15 to $30 \mathrm{~s}$, to buffer whereas high molarity acids and bases took a little longer, 30 to $45 \mathrm{~s}$. This time is within the range of the average residence time of materials in the barrels of the extruder (30 to $75 \mathrm{~s}$ ). The buffering effect is seen with both acid and alkali; although the 


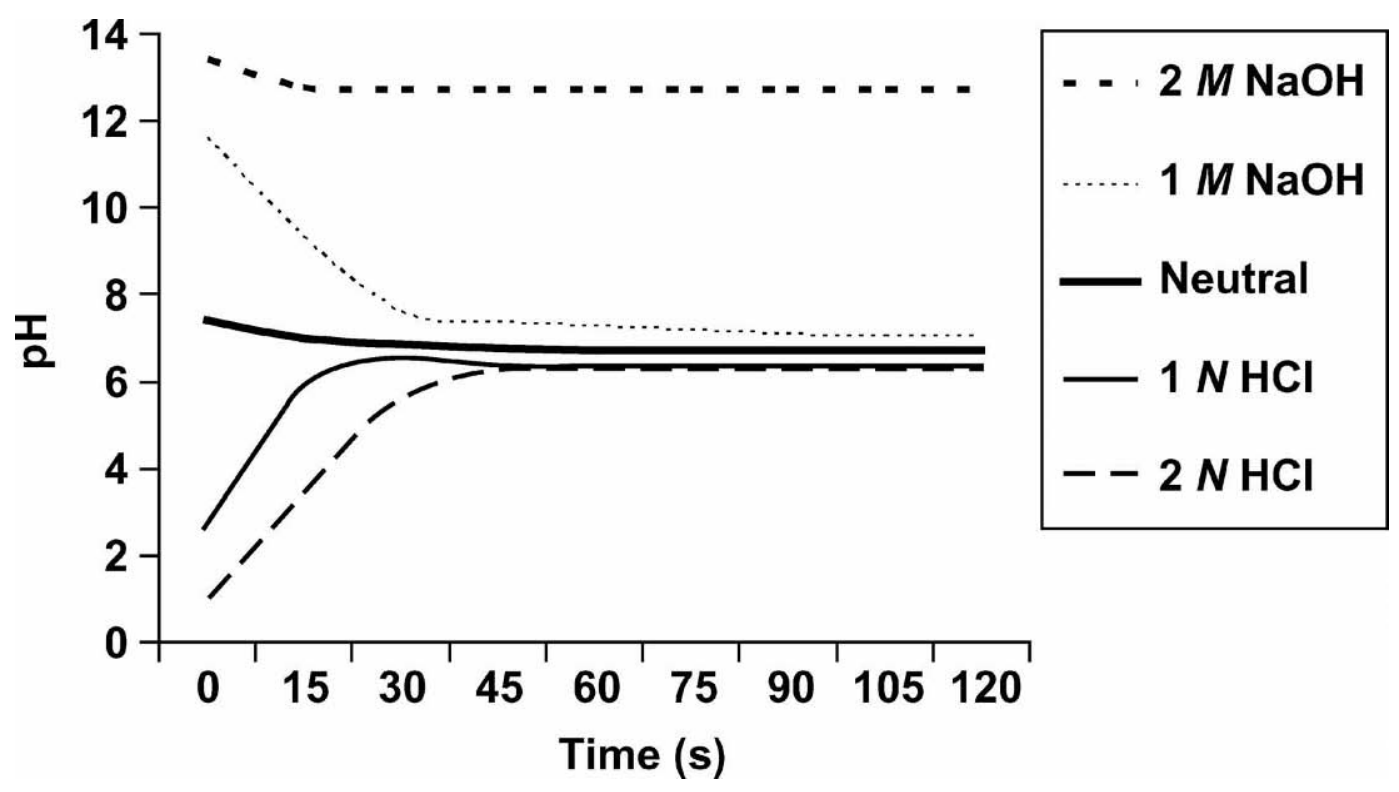

Figure 1. The buffering properties of extruded whey protein isolates adjusted with 5 different pH-adjusted waters as follows: $1 \mathrm{~N}$ HCl (pH 2.62), $2 \mathrm{~N} \mathrm{HCl} \mathrm{(pH} \mathrm{1.4),} \mathrm{deionized} \mathrm{water} \mathrm{(pH} \mathrm{7.2),} 1 N$ NaOH (pH 11.6), and $2 \mathrm{~N} \mathrm{NaOH} \mathrm{(pH} \mathrm{13.2).}$

materials start with different $\mathrm{pH}$ conditions, they end up close to the normal $\mathrm{pH}$ of WPI, $\mathrm{pH} 6.2 \pm 0.2$. The short time $(<30 \mathrm{~s})$ to complete buffering means that all reactions are carried out within the extruder, allowing for maximum short-term effect with minimal long-term alteration of the proteins. Buffering capacity of milk is due to the presence of protein and salts (Walstra et al. 1999). In general, whey proteins have maximum buffering capacity between $\mathrm{pH} 3$ and 4 for proteins with acidic residues and $\mathrm{pH}>8$ for those with alkaline residues (Salaun et al., 2005). For this experiment, we used acid-precipitated whey proteins, which reportedly have higher buffering capacity due to higher inorganic mineral content, particularly phosphates. Heat treatment of whey proteins has been shown to increase buffering capacity (Lucey et al., 1993). The combination of shear and heat treatment explains the short buffering times observed in this study.

There was a significant $(P<0.05)$ difference in solubility between nonextruded pastes (NEXT) and the $\mathrm{pH}$ adjusted extrudates. The solubility of extruded WPI was affected by $\mathrm{pH}$ of the water (Table 1). There was a slight increase ( 18 to $20 \%)$ in solubility associated with acid extrudates over the extruded control (NEUT). The difference between EACI and HACI extrudates was not significant, but both were higher in solubility than NEUT. The electrolyzed alkali extrudates were similar to the control, but significantly more denatured than the other $\mathrm{pH}$-adjusted products.

The effect of $\mathrm{pH}$ on yellowness values and total color difference $(\Delta \mathrm{E})$ of WPI extrudates is shown in Table 1.
On the color scale, the b coordinate is a measure of yellowness. All pH-adjusted extruded samples were significantly $(P<0.05)$ more yellow and darker than the NEXT paste. The yellowness order was NEXT ( $\mathrm{pH} 6.8)$ $<$ HACI $(\mathrm{pH}$ 1.4), NEUT $(\mathrm{pH}$ 6.8) < EACI $(\mathrm{pH} 2.5)<$ EALK ( $\mathrm{pH} 11.5)<$ NALK ( $\mathrm{pH}$ 13.2). Examination of the b coordinates of WPI extrudates show that the most yellow were NALK extrudates (Figure 2). The 2 acid WPI extrudates were similarly bright, and were brighter than NEUT, but slightly darker than NEXT. The NALK extrudates were significantly darker $(P<0.05)$, indicating very strong effect of alkaline conditions. The total

Table 1. The effect of $\mathrm{pH}$ of extruded whey protein isolates (WPI) on the solubility and color of WPI

\begin{tabular}{llll}
\hline $\begin{array}{l}\text { Extrusion } \\
\text { condition }^{1}\end{array}$ & $\begin{array}{l}\text { Solubility } \\
(\%)\end{array}$ & $\begin{array}{l}\text { Color } \\
(\mathrm{b})\end{array}$ & $\begin{array}{l}\text { Color } \\
\text { difference } \\
(\Delta \mathrm{E})\end{array}$ \\
\hline EACI (pH 2.5) & $22.3^{\mathrm{b}}$ & $10.9^{\mathrm{b}}$ & $89.9^{\mathrm{b}}$ \\
HACI (pH 1.4) & $21.8^{\mathrm{b}}$ & $9.1^{\mathrm{bc}}$ & $89.8^{\mathrm{b}}$ \\
NEUT (pH 6.8) & $18.4^{\mathrm{c}}$ & $9.1^{\mathrm{bc}}$ & $86.9^{\mathrm{bc}}$ \\
EALK (pH 11.5) & $18.6^{\mathrm{c}}$ & $12.1^{\mathrm{b}}$ & $90.3^{\mathrm{b}}$ \\
NALK (pH 13.2) & $15.3^{\mathrm{d}}$ & $15.7^{\mathrm{a}}$ & $73.8^{\mathrm{c}}$ \\
NEXT (pH 6.8) & $73.5^{\mathrm{a}}$ & $6.7^{\mathrm{c}}$ & $94.7^{\mathrm{a}}$ \\
\hline
\end{tabular}

${ }^{\mathrm{a}-\mathrm{d}}$ Means within a column with the same letter are not significantly different $(P<0.05)$.

${ }^{1} \mathrm{EACI}=$ WPI Extruded at $\mathrm{pH} 2.5$ with electrolyzed acid water; HACI = WPI extruded at $\mathrm{pH} 1.4$ with $2 \mathrm{~N}$ HCl-adjusted water; NEUT $=$ WPI extruded at $\mathrm{pH} 6.8$ with deionized water; EALK = WPI extruded at $\mathrm{pH} 11.5$ with electrolyzed alkali water; NALK = WPI extruded at pH 13.2 with $2 M \mathrm{NaOH}$-adjusted water; NEXT = nonextruded WPI paste.

${ }^{2} \Delta \mathrm{E}$ is the total color difference. 

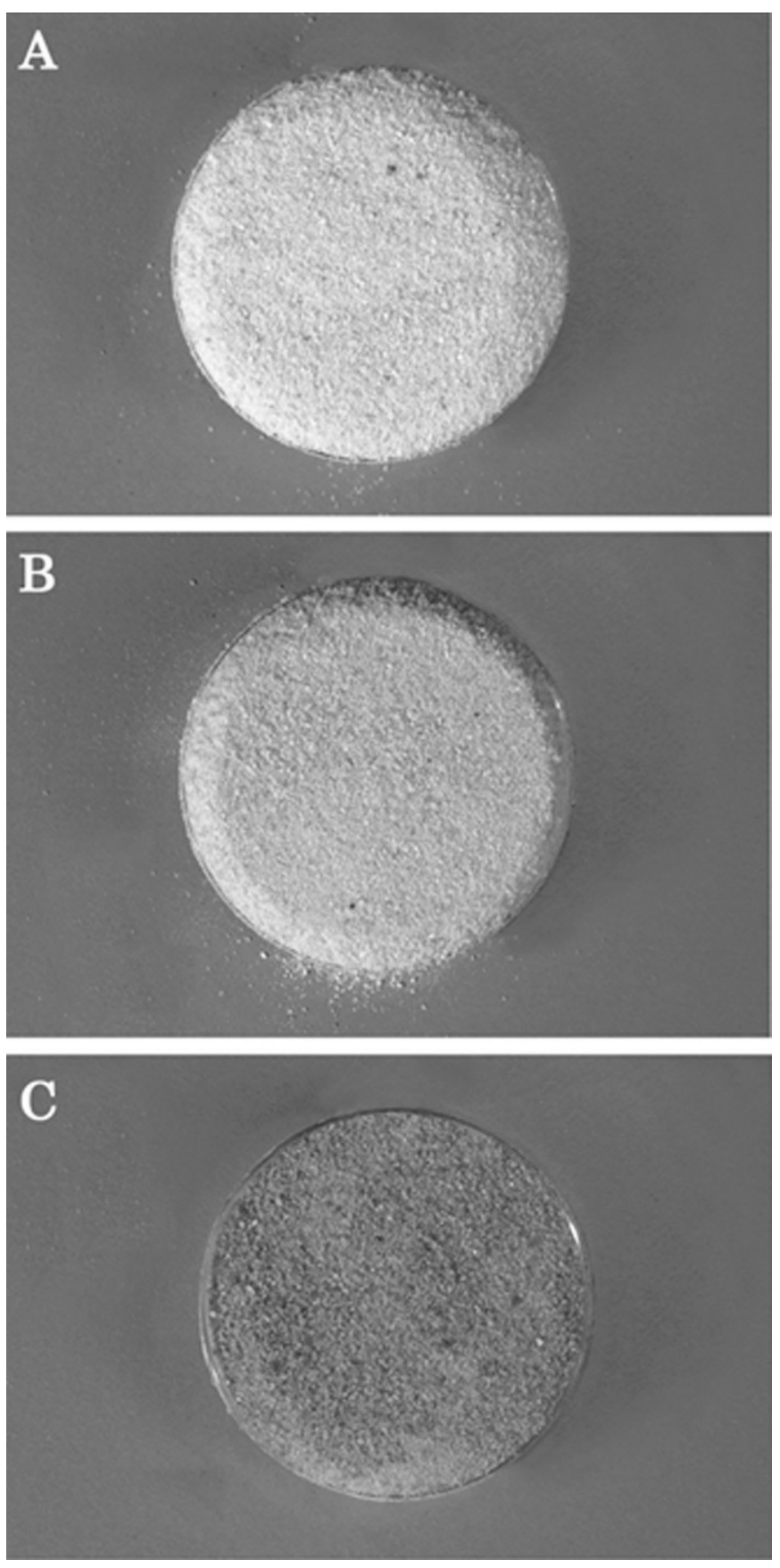

Figure 2. Photograph showing the effect of $\mathrm{pH}$ on extruded whey protein isolates. A) HACI (extruded at $\mathrm{pH} 1.4$ with electrolyzed acid water); B) NEUT (extruded at $\mathrm{pH} 6.8$ with deionized water); and C) NALK (extruded at $\mathrm{pH} 13.2$ with $2 \mathrm{~N} \mathrm{NaOH}$-adjusted water).

color difference of EALK extrudate was brighter than NALK, indicating less effect. Yellowness may be the effect of ammonium sulfide, olfactorally perceptible from NALK extrudates.

Rapid Visco analysis is a time-temperature profile or pasting viscogram of a material that show the points of
Table 2. The effect of $\mathrm{pH}$ of whey protein isolates (WPI) on the Rapid Visco Analyzer pasting properties of extruded WPI

\begin{tabular}{lccc}
\hline $\begin{array}{l}\text { Extrusion } \\
\text { condition }^{1}\end{array}$ & $\begin{array}{l}\text { Peak } \\
\text { viscosity } \\
(\mathrm{cP})\end{array}$ & $\begin{array}{l}\text { Final } \\
\text { viscosity } \\
(\mathrm{cP})\end{array}$ & $\begin{array}{l}\text { Setback } \\
\text { viscosity } \\
(\mathrm{cP})\end{array}$ \\
\hline EACI (pH 2.5) & $34^{\mathrm{d}}$ & $23^{\mathrm{b}}$ & $14^{\mathrm{b}}$ \\
HACI (pH 1.4) & $108^{\mathrm{b}}$ & $268^{\mathrm{a}}$ & $171^{\mathrm{a}}$ \\
NEUT (pH 6.8) & $96^{\mathrm{bc}}$ & $263^{\mathrm{a}}$ & $175^{\mathrm{a}}$ \\
EALK (pH 11.5) & $128^{\mathrm{b}}$ & $320^{\mathrm{a}}$ & $202^{\mathrm{a}}$ \\
NALK (pH 13.2) & $208^{\mathrm{a}}$ & $381^{\mathrm{a}}$ & $186^{\mathrm{a}}$ \\
\hline
\end{tabular}

${ }^{\mathrm{a}-\mathrm{d}}$ Means within a column with the same letter are not significantly different $(P<0.05)$.

${ }^{1} \mathrm{EACI}=$ WPI Extruded at $\mathrm{pH} 2.5$ with electrolyzed acid water; HACI $=$ WPI extruded at $\mathrm{pH} 1.4$ with $2 \mathrm{~N}$ HCL-adjusted water; NEUT $=$ WPI extruded at $\mathrm{pH} 6.8$ with deionized water; EALK = WPI extruded at $\mathrm{pH} 11.5$ with electrolyzed alkali water; NALK = WPI extruded at $\mathrm{pH} 13.2$ with $2 M \mathrm{NaOH}$-adjusted water; $\mathrm{NEXT}=$ nonextruded WPI paste.

peak, final, and setback viscosities (Almeida-Dominguez et al., 1994). Peak viscosity is the first peak in the swelling region that characterizes viscous properties. Pasting properties reveal important information about a product's degree of denaturation, and the effect of processing conditions on degree of denaturation (DesRochers, 1998). The RVA peak viscosities for gels of $\mathrm{pH}$-adjusted texturized WPI (Table 2) show the NALK extrudate to be significantly more viscous than the rest of the samples. The rest of the samples were similar to the neutral extrudate, but EACI was less viscous than its control (NEUT). Final and setback viscosities were similar for all extrudates except EACI, which was significantly lower $(P<0.05)$. The effect of $\mathrm{pH}$-adjustment on protein pasting properties depended on the molar strength of the solution used to adjust $\mathrm{pH}$.

Differences in structure of the WPI extrudates produced under different $\mathrm{pH}$ conditions were probed by macroscopic and microscopic imaging. Cross-sections of extruded ribbons illustrate several differences, examined by stereomicroscopy (Figure 3, panels A, B and C). At $\mathrm{pH}$ 1.4, the ribbons were narrow and dry, and frequently split horizontally along the midline, while the outer edges were smooth. At neutral $\mathrm{pH} 6.8$, the ribbons were slightly thicker and moist with rough or fluted edges; and at alkaline $\mathrm{pH}$, the ribbons were thickest, moist, and the edges were irregular on a submillimeter scale. When the edges of the ribbons were examined by fluorescence confocal microscopy, the differences in structure were apparent, especially at the edges. Following extrusion, the ribbons were immersed in a glutaraldehyde solution; the reaction of glutaraldehyde with protein typically produces autofluorescence in the visible light spectrum, which can be imaged with a confocal laser scanning microscope or other epifluorescence imaging system. When excited with blue light $(488 \mathrm{~nm})$ from an argon laser, the protein-glutaraldehyde com- 

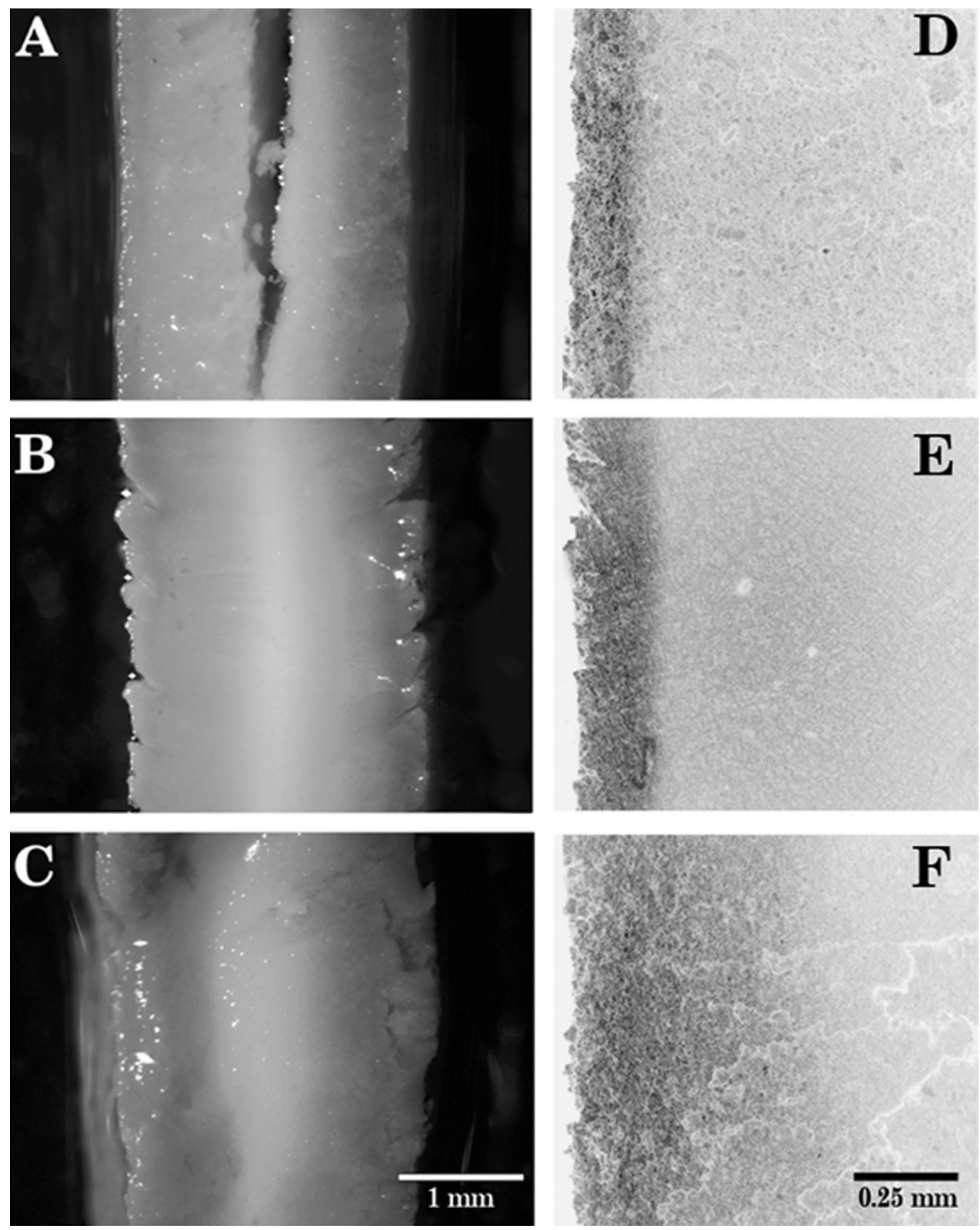

Figure 3. Two sets of images illustrating the effects of $\mathrm{pH}$ on extruded whey protein isolate ribbons. A (HACI; extruded at pH 1.4 with electrolyzed acid water), B (NEUT; extruded at $\mathrm{pH} 6.8$ with deionized water), and C (NALK; extruded at $\mathrm{pH} 13.2$ with $2 \mathrm{~N}$ NaOH-adjusted water) are cross-sections of extruded ribbons imaged by reflected light illustrating general features and variations in color following fixation in glutaraldehyde solution; D (HACI), E (NEUT), and F (NALK) are confocal microscope images including edges of the cross sections demonstrating the differences in breadth of the dense bands and granularities that correspond to intense autofluorescence.

plexes in the WPI extrudates emitted visible fluorescence extending from 500 to $>600 \mathrm{~nm}$. When maximum projection images at the cross-sectioned edges of the ribbons were made, distinct differences in the distribution of fluorescence were apparent, depending on the $\mathrm{pH}$ of the extrusion process. At $\mathrm{pH}$ 1.4, a narrow region of the edge $(<250 \mu \mathrm{m})$ was most intense, but the whole edge area was composed of numerous irregular, fluorescent granules, with dimensions up to about $50 \mu \mathrm{m}$ in diameter (Figure 3D). Similarly, ribbons extruded at neutral $\mathrm{pH}$ 


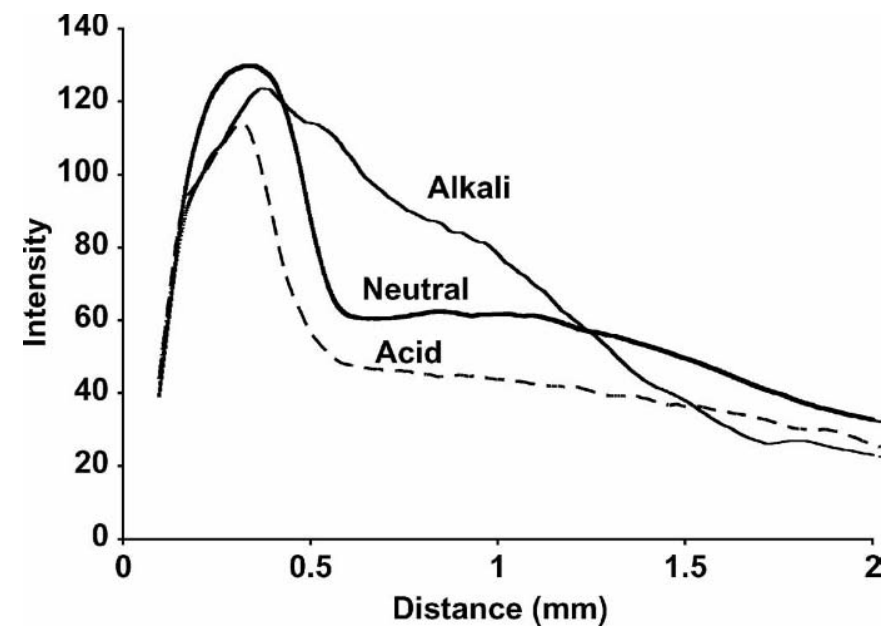

Figure 4. Plots of the horizontally averaged relative intensities in Figure $3 \mathrm{D}, \mathrm{E}$ and $\mathrm{F}$, showing the edge effects at the different $\mathrm{pH}$ values.

also had a thin bright edge, including the superficial irregularities $(<250 \mu \mathrm{m})$ but the matrix of the ribbon contained nearly uniform fluorescence that was not resolved in the form of granules compared with the acid $\mathrm{pH}$ ribbons (Figure 3E). Notably, at alkaline $\mathrm{pH}$, the increased fluorescence intensity at the edge was much deeper or broader than that of the others, extending more than $500 \mu \mathrm{m}$ from the edges, and the intensity decreased gradually, rather than abruptly as in the acid and neutral $\mathrm{pH}$ samples (Figure 3F). For comparison, profiles of the fluorescence intensities from each type of ribbon were made by averaging the intensity along the horizontal axis of each image, and the computed line profiles for the maximum projection images are illustrated in Figure 4. The comparison reveals that at acid and neutral $\mathrm{pH}$, the intensities of fluorescence are maximal at short distances $(<250 \mu \mathrm{m})$ from the edge, and they drop sharply to a baseline level. The intensity peak at alkaline $\mathrm{pH}$ also occurs at a depth of less than 250 $\mu \mathrm{m}$, but the intensity does not drop rapidly to low levels; instead, fluorescence extends at more than one-half the peak height to depths of more than $500 \mu \mathrm{m}$ into the matrix of the ribbon. These results suggest that the $\mathrm{pH}$ conditions of extrusion affect the aggregation and conformation of the WPI proteins in the ribbons, as expressed by a differential reaction with glutaraldehyde, producing different patterns of autofluorescence. Averaged intensities along the horizontal axes of the images are compared in Figure 4. A maximum projection image of the fluorescent surface of the 3 extrudates shows different degrees of aggregation, and that HACI extrudates were most aggregated (see Figure 3D). The HACI extrudates were aggregated into the most discrete, granular-shaped fluorescent material, delineated by narrow spaces with no fluorescence. The NEUT extrudates had the most continuous, and least well-defined fluorescence (see Figure 3E) and in the alkaline extrudates, the fluorescent material was aggregated into particles or clumps (Figure $3 \mathrm{~F}$ ).

Compared with NEXT (pH 6.8; Figure 5A) and NEUT (Figure 5B) pastes, the folding of the acid and alkali samples are more extensive. The fluorescence images of the surfaces of HACI and NALK extrudates (Figures 5C and 5D) show different folding patterns or aggregation from the control extrudates. The NALK extrudate has large folds, whereas the HACI folds are smaller with spaces in the matrix. The increased folding with HACI and NALK extrudates suggests greater insolubility or denaturation. This was confirmed by the solubility analysis (Table 1). Under acid conditions, the autofluorescence was clustered into the form of small, well-defined particles ranging from less than 1 to $2 \mu \mathrm{m}$ in diameter and under neutral conditions the distribution of intensity was similar. Alkaline conditions produced broader distribution of sizes and less well-defined shapes of fluorescent aggregates.

The $\mathrm{pH}$ of the electrolyzed water created the visible differences in the organization of the fine structures of products extruded with electrolyzed water and may have been the result of electrolysis products. The autofluorescence from the 2 electrolyzed water extrudates, EACI and EALK, showed different degrees of aggregation, with acid extrudates being more aggregated (Figure 6A) than the alkali extrudates (Figure 6B). These images show the fluorescence variation due to degree of aggregation and differences in clumping. Extruded samples contain dense aggregates of material with irregular shapes and sizes, interspersed with electron-lucent areas with smaller aggregates (Figure 7). Ultrastructure in the dense clumps resembles the fine granularity $(5 \mathrm{~nm})$ found in the fully denatured materials examined previously (Onwulata et al., 2003). Control samples (NEXT and NEUT) did not contain the irregular dense clumps of material; instead the ultrastructure is a uniform dispersion of loosely packed small clumps, containing very fine granularity $(5 \mathrm{~nm})$ unlike the long periodicity (200 to $300 \mathrm{~nm}$ ) found in the fully hydrated "gel". When examined by transmission electron microscopy of stained thin sections, nonextruded WPI paste was homogeneous, consisting of fine granules around $5 \mathrm{~nm}$ in diameter and short threads about 15 to $25 \mathrm{~nm}$ long (Figure 7A). At neutral $\mathrm{pH}$ (Figure 7B), the ultrastructure of the extrudate contained regular, circular or ellipsoidal electrondense aggregates ranging from under 100 to over 300 $\mathrm{nm}$ in diameter, and the aggregates were separated by less electron-dense areas containing randomly oriented threads, around $5 \mathrm{~nm}$ wide and $100 \mathrm{~nm}$ long in the interstices that merge with the surfaces of the closepacked aggregates. At acid and alkaline $\mathrm{pH}$ (Figure 7C 

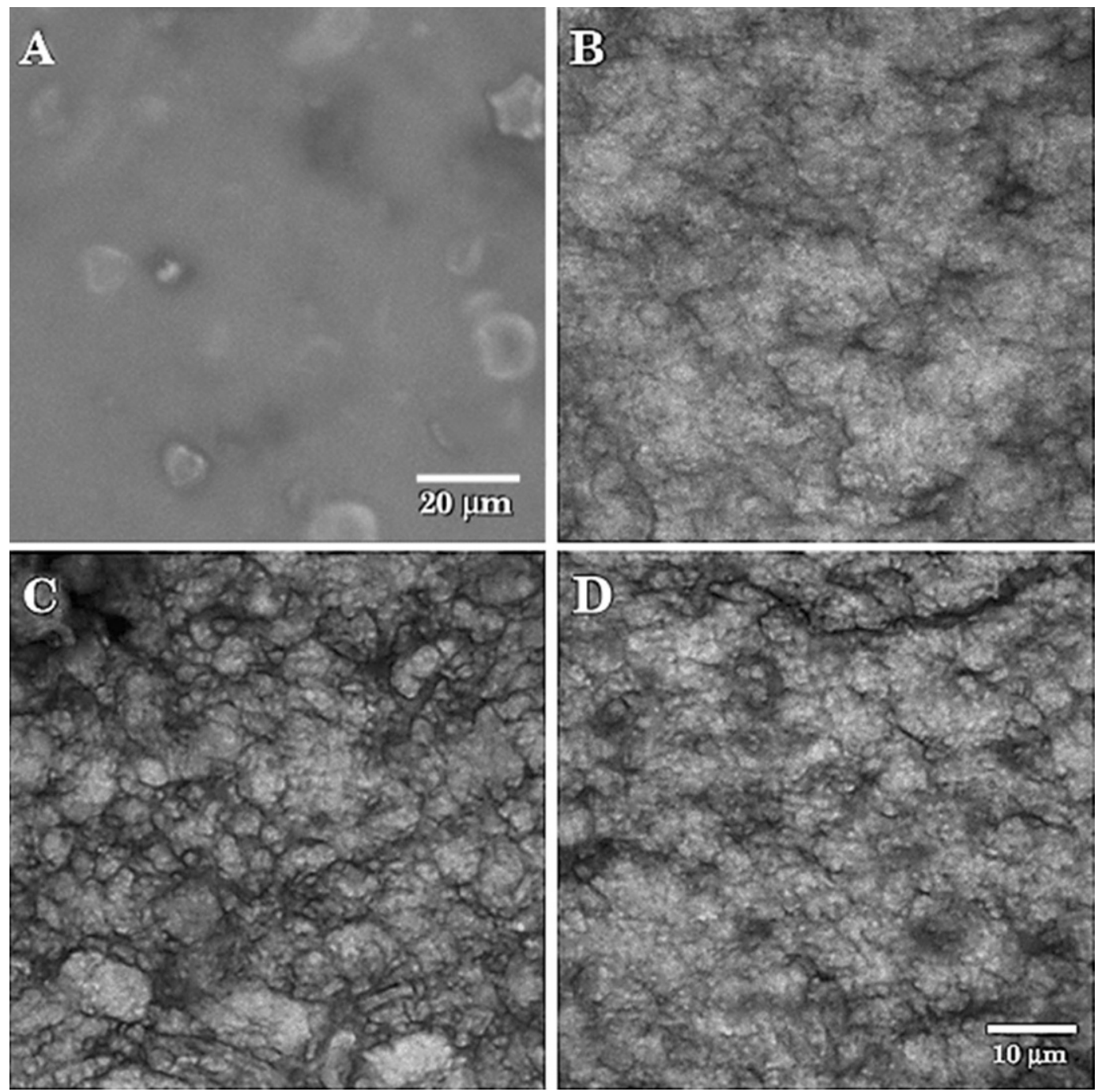

Figure 5. Confocal fluorescence images illustrating the effects of $\mathrm{pH}$ on the microstructure of whey protein isolate (WPI) ribbons: A) diffuse fluorescence in NEXT (nonextruded WPI paste); B) diffuse clusters of fluorescence in NEUT (WPI extruded at pH 6.8 with deionized water); C) and D) well defined, cumulative clusters of fluorescence in HACI (WPI extruded at pH 1.4 with $2 \mathrm{~N}$ HCl-adjusted water) and NALK (WPI extruded at $\mathrm{pH} 13.2$ with $2 \mathrm{~N} \mathrm{NaOH}$-adjusted water), respectively.

and D), the ultrastructure of extrudates contained very large, irregular electron-dense aggregates, separated by equally large and irregular areas of low electron density filled with short threads that were confluent with the surfaces of the aggregates, similar to those found at neutral $\mathrm{pH}$.

Although it is known that $\mathrm{pH}$ buffering (the resistance to change in $\mathrm{pH}$ on addition of acid or base) retards any physical modification of WPI (Fox and McSweeney, 1998), we observed in this study that buffering of WPI was more effective with comparatively weaker acids and bases, but not with strong acids and bases (Figure 1). Buffering capacity can be altered depending on the severity of heat treatment of various milk protein fractions (Salaun et al., 2005). Heat treatment lower than $100^{\circ} \mathrm{C}$ for 10 min induced a slight increase in buffering capacity at $\mathrm{pH} 5$ of milk, whereas intense heat treatment at $120^{\circ} \mathrm{C}$ for 10 min increased its buffering capacity intensely and shifted maximum peak $\mathrm{pH}$ (Lucey et al., 1993). Gezimati et al. (1998) showed that combining heating and shear alters the conformational structure of the protein by exposing groups that are normally hidden away in the native protein.

We have reported here that extrusion induces sheargenerated structural changes leading to loss of solubility with increasing $\mathrm{pH}$ in a short time $(<40 \mathrm{~s})$. Previously, Kavanagh et al. (2000) showed that mixtures of $\alpha$-LA and $\beta$-LG formed coupled network gels at $\mathrm{pH} 3$ and 7, and fine-stranded fiber-like aggregates at $\mathrm{pH} 2$, in the presence of $0.1 \mathrm{M} \mathrm{NaCl}$, and that aggregation of globules 

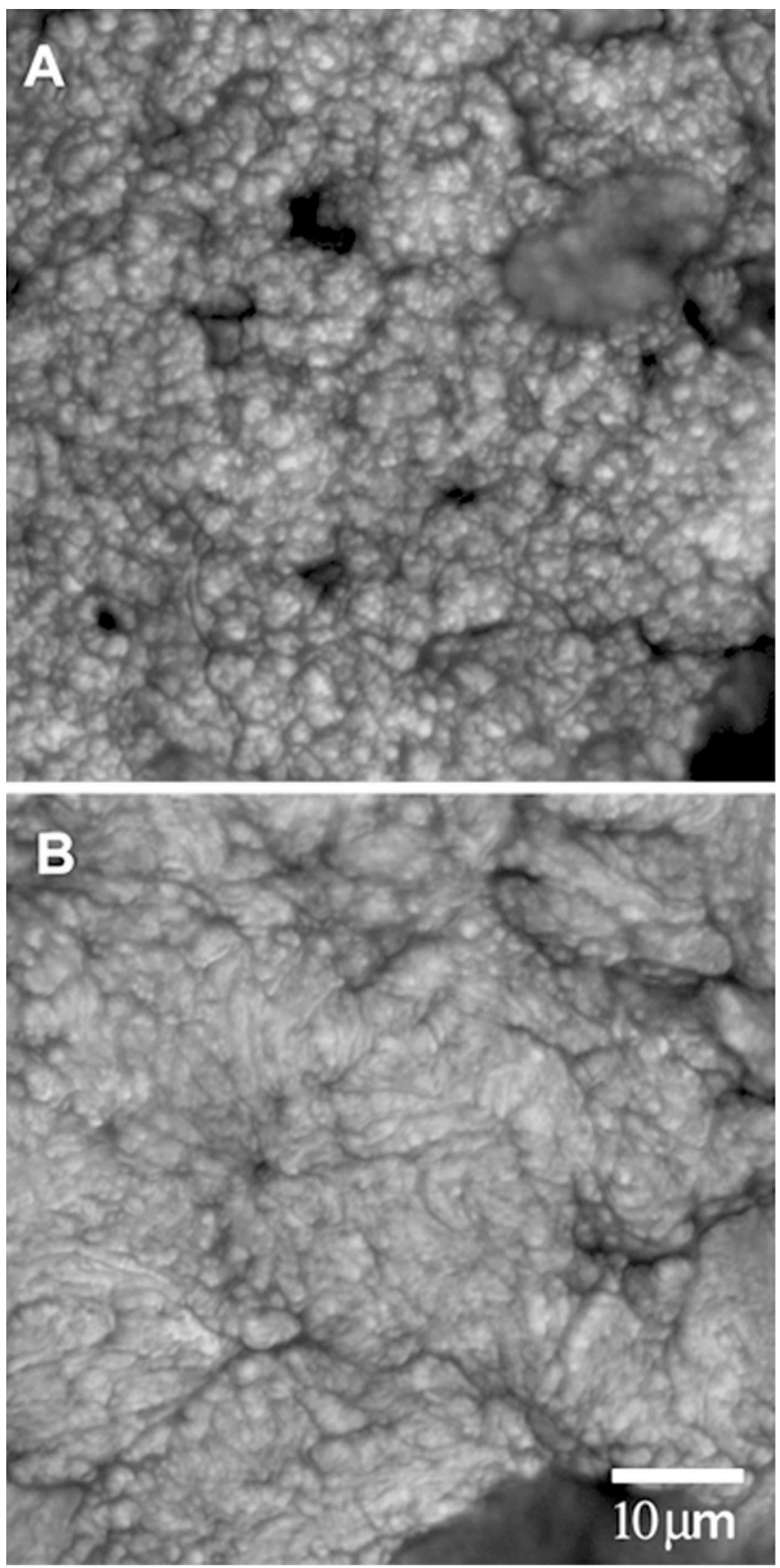

Figure 6. Confocal fluorescence images illustrating the effects of $\mathrm{pH}$ on the microstructure of whey protein isolate (WPI) ribbons showing well defined, cumulative clusters of fluorescence: A) diffuse fluorescence in EACI (WPI extruded at $\mathrm{pH} 2.5$ with electrolyzed acid water); and B) diffuse clusters of fluorescence in EALK (WPI extruded at $\mathrm{pH} 13.2$ with $2 \mathrm{~N} \mathrm{NaOH}$-adjusted water).

occurred at $\mathrm{pH}$ 7. They showed also that aggregation occurs more with acid because of modest increases in intermolecular $\beta$-sheet with shoulder, which develops in the carbonyl-stretching amide I region. Our results
(Figures 5 and 6) confirm the formation of aggregates, and shows further varying degrees of aggregation induced by shear and acidic conditions, and demonstrated that NALK samples produced with water adjusted with $2 \mathrm{~N} \mathrm{NaOH}$ at $\mathrm{pH} 13$ were most aggregated.

The network structure in a heat-induced globular gel depends strongly on the balance between the attractive and repulsive forces during aggregation. If the $\mathrm{pH}$ is far from the isoelectric point, and the ionic strength is sufficiently low, then intermolecular electrostatic repulsion is dominant. Structural transitions are reflected by the macroscopic properties-fine-stranded gels are translucent, whereas particulate gels are opaque and syneretic. A fine-stranded gel formed at neutral $\mathrm{pH}$ is rubbery and deformable to a large strain without fracturing (Ikeda and Morris, 2002). At acidic $\mathrm{pH}$, intramolecular disulfide bonding is unlikely to occur; the structures are brittle. Our results show brittleness of HACI extrudate $\mathrm{pH}$ (1.4) with fractures (Figure 3A). Bilayer fluorescent patterns of protein and glutaraldehyde complexes observed through confocal scanning laser microscopy (Figure 4) agree with the observation that heat induces gelation of globular proteins at low $\mathrm{pH}$ (2 to 2.5), and at the molecular level, rod-like structures are formed (Onwulata et al., 2003), whereas aggregation of globules occurs at $\mathrm{pH}$ 7. Gosal et al. (2004a) showed that $\beta$-LG formed aggregates with worm-like fibrils when heated in various alcohol-water mixtures at $\mathrm{pH} 2$, and that thermally induced aggregation occurred more cooperatively in a nucleation and growth process. At higher concentrations, heated $\beta$-LG self-assembled in a uniform fibrillar pattern (Gosal et al., 2004b). It is reasonable to consider that whey protein aggregates generated under extrusion at high temperature would also contain more aligned fibrillar structures. Finally, Pelegrine and Gasparetto (2005) have shown that strong links between $\mathrm{pH}$ and temperature affect solubility of whey proteins in the $\mathrm{pH}$ range 3.5 to 7.8 and temperature range of 40 to $60^{\circ} \mathrm{C}$ and that denaturation occurs. We show that extrusion texturization occurs in the short time frame of 15 to 60 $\mathrm{s}$ within the extruder; therefore, $\mathrm{pH}$-adjusted extrusiontexturized WPI will maintain their characteristic quality after treatment, and provide added functionality due to newly induced conformation.

\section{CONCLUSIONS}

Denaturation and aggregation of whey protein isolates are $\mathrm{pH}$ dependent, with strong alkalis producing the more textural effect. Denaturation at the molecular level produces rod-like microstructures and forms the basis for fine-stranded fiber-like structures in texturized products. We have demonstrated that whey protein can be texturized by high shear at different $\mathrm{pH}$ values to form 

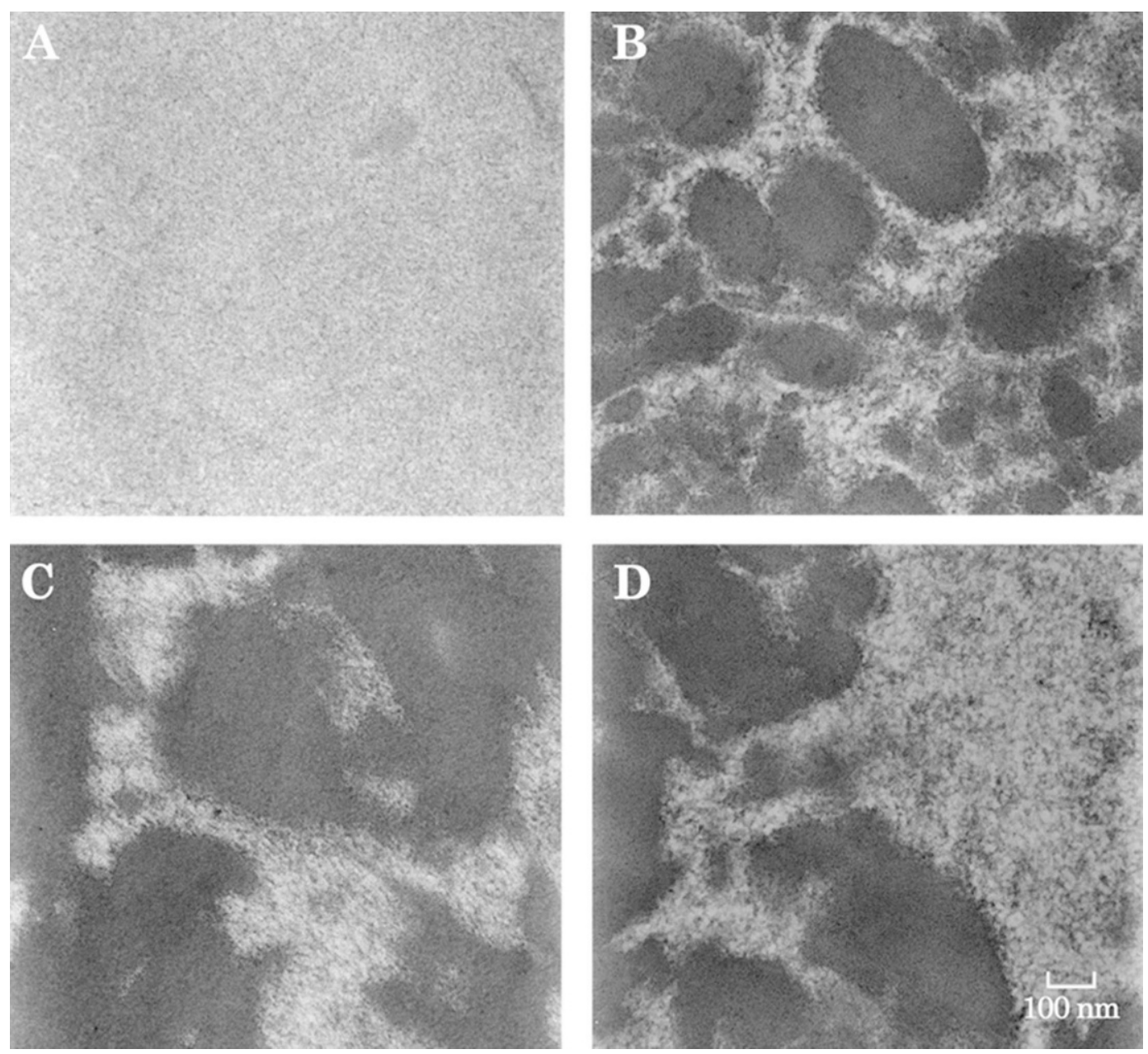

Figure 7. Thin sections of embedded whey protein isolate (WPI) ribbons illustrating the ultrastructure of the protein aggregates: A) uniform, fine granularity of EACI (WPI extruded at $\mathrm{pH} 2.5$ with electrolyzed acid water); B) micrometer- and submicrometer-diameter circular dense aggregates surrounded by fine filaments in the interstices in NEUT (WPI extruded at pH 6.8 with deionized water); C) and D) irregular dense aggregates and interstitial filaments in EALK (WPI extruded at $\mathrm{pH} 11.5$ with electrolyzed alkali water) and NALK (WPI extruded at $\mathrm{pH} 13.2$ with $2 \mathrm{~N} \mathrm{NaOH}$-adjusted water), respectively.

stringy products. Whey proteins denatured under acidic and alkaline conditions form small primary aggregates that combine to form large clusters and are aligned by extrusion shear to form fibrous structures. Fibrous protein extrudates may be spun into meat alternatives similar to textured soy products.

\section{ACKNOWLEDGMENTS}

The authors appreciate the help of Zerlina Muir with chemical and physical assays, and that of Jamal Booker and John Mulherin with extrusion processing.

\section{REFERENCES}

Almeida-Dominguez, H. D., M. M. Ku-Kumul, C. M. McDonough, and

L. W. Rooney. 1994. Effect of extrusion parameters on physico- chemical and pasting characteristics of a food type white sorghum. AACC RVA Symposium, Applications of the Rapid Visco Analyzer. C. E. Walker and J. L. Hazelton, ed. New Port Scientific Pty. Ltd., Warriewood, NSW, Australia.

Anema, S. G., E. K. Lowe, and Y. M. Li. 2004. Effect of $\mathrm{pH}$ on the viscosity of heated reconstituted skim milk. Int. Dairy J. $14: 541-548$

AOAC. 1998. Official Methods of Analysis. 16th ed. Association of Official Analytical Chemists, Washington, DC.

Atkinson, W. T. 1970. Meat-like protein food products. U.S. Patent \#3,488,770. Archer Daniel Midlands Co., Minneapolis, MN; assignee.

Batterman-Azcona, S. J., and B. R. Hamaker. 1998. Changes occurring in protein body structures and alpha-zein during corn flakes processing. Cereal Chem. 75:217-221.

Breitenbach, J. 2002. Melt extrusion: From process to drug delivery technology. Eur. J. Pharm. Biopharm. 54:107-117.

Dahl, S. R., and R. Villota. 1991. Twin-screw extrusion texturization of acid and alkali denatured soy protein. J. Food Technol. 56:1002-1007.

DesRochers, J. L. 1998. Comparison of starch pasting properties in oat ring-type breakfast cereals. Cereals Foods World 43:646-649. 
Ennis, M. P., and D. M. Mulvihill. 2000. Milk proteins. Pages 189217 in Handbook of Hydrocolloids. G. O. Phillips and P. A. Williams, ed. CRC Press, Boca Raton, FL.

Fox, P. F., and P. L. H. McSweeney. 1998. Physical properties of milk. Pages 437-461 in Dairy Chemistry and Biochemistry. P. F. Fox and P. L. H. McSweeney, ed. Blackie Academic \& Professional, New York, NY.

Gezimati, J., L. K. Creamer, and H. Singh. 1998. Heat-Induced hydrophobically bonded aggregates involving both alpha-lactalbumin and beta-lactoglobulin. J. Agric. Food Chem. 45:1130-1136.

Gosal, W. S., A. H. Clark, and S. B. Ross-Murphy. 2004a. Fibrillar $\beta$ lactoglobulin gels: Part 1. Fibril formation and structure. Biomacromolecules 5:2408-2419.

Gosal, W. S., A. H. Clark, and S. B. Ross-Murphy. 2004b. Fibrillar $\beta$ lactoglobulin gels: Part 2. Dynamic mechanical characterization of heat-set systems. Biomacromolecules 5:2420-2429.

Hale, A. B., C. E. Carpenter, and M. K. Walsh. 2002. Instrumental and consumer evaluation of beef patties extended with extrusiontextured whey proteins. J. Food Sci. 67:1267-1270.

Harper, J. M. 1981. Extrusion of Foods. Vol. I. CRC Press, Boca Raton, FL.

Harwalker, V. R. 1979. Comparison of physico-chemical properties of different thermally denatured whey proteins. Milchwissenschaft $34: 419-422$.

Ikeda, S., and V. J. Morris. 2002. Fine-stranded and particulate aggregates of heat-denatured whey proteins visualized by atomic force microscopy. Biomacromolecules 3:382-389.

Kato, A., Y. Hara, E. Arai, and R. Onishi. 2001. Preparation method of dough for flour foods. U.S. Patent. 6,326,048. Hoshizaki Denki Kabushiki Kaisha, Japan; assignee.

Kavanagh, G. M., A. H. Clark, and S. B. Ross-Murphy. 2000. Heatinduced gelation of globular proteins: Part 3. Molecular studies on low $\mathrm{pH} \beta$-lactoglobulin gels. Int. J. Biol. Macromol. 28:41-50.

Kester, J. J., and T. Richardson. 1984. Modification of whey proteins to improve functionality. J. Dairy Sci. 67:2755-2774.

Kobayashi, K., N. Tosa, Y. Hara, and S. Horie. 1996. An examination of cooked rice with electrolyzed water. Nippon Shokuhin Kagayu Kogaku Kaisha 43:930-938.

Kobayashi, K., and Y. Yamasaki. 1997. An examination of cooked rice with electrolyzed water. Nippon Shokuhin Kagaku Kogaka Kaishi 43:930-938.
Kilara, A. 1984. Standardization of methodology for evaluating whey proteins. J. Dairy Sci. 67:2734-2744.

Kim, C. H., and J. A. Maga. 1987. Properties of extruded whey protein concentrate and cereal flour blends. Lebensm. Wiss. Technol. 20:311-318.

Kitabatake, N., D. Megard, and J. C. Cheftel. 1985. Continuous gel formation by HTST extrusion-cooking: Soy proteins. J. Food Sci. 50:1260.

Linden, G., and D. Lorient. 1999. The exploitation of by-products. Pages 184-210 in New Ingredients in Food Processing: Biochemistry and Agriculture. G. Linden and D. Lorient, ed. CRC Press, Boca Raton, FL.

Lucey, J. A., C. Gorry, and P. F. Fox. 1993. Acid-base buffering properties of heated milk. Milchwissenschaft 48:438-441.

Onwulata, C. I., R. P. Konstance, P. H. Cooke, and H. M. Farrell. 2003. Functionality of extrusion-texturized whey proteins. J. Dairy Sci. 86:3775-3782.

Onwulata, C. I., R. P. Konstance, P. W. Smith, and V. H. Holsinger. 2001. Incorporation of whey products in extruded corn, potato or rice snacks. Food Res. Int. 34:679-687.

Onwulata, C. I., and P. M. Tomasula. 2004. Whey texturation: A whey forward. Food Technol. 58(7):50-54

Parkes, N. E., L. E. Bennett, and M. L. Bason. 1998. Novel viscometric methods to assess processing effects on milk proteins. Proc. 25th Int. Dairy Congr., Aarhus, Denmark. IDF, Brussels, Belgium.

Pelegrine, D. H. G., and C. A. Gasparetto. 2005. Whey proteins solubility as function of temperature and $\mathrm{pH}$. Lebensm. Wiss. Technol. 38:77-80.

Queguiner, C., E. Dumay, C. Salou-Cavalier, and J. C. Cheftel. 1992 Microcoagulation of a whey protein isolate by extrusion cooking at acid pH. J. Food Sci. 57:610-616.

Rhee, K. C., C. K. Kuo, and E. W. Lusas. 1981. Texturization. ACS Symp. Ser. 147:52

Salaun, F., B. Mietton, and F. Gaucheron. 2005. Buffering capacity of dairy products. Int. Dairy J. 15:95-109.

Walstra, P., T. J. Geurts, A. Noomen, A. Jellema, and M. A. J. S. van Boekel. 1999. Pages 189-199 in Dairy technology: Principles of milk properties and processes. P. Walstra, T. J. Geurts, A. Noomen, A. Jellema, and M. A. J. S. van Boekel, ed. Marcel Dekker, Inc., New York, NY. 